\title{
Influence of Disaccharides on the Development of Systemic Acidosis in the Premature Infant
}

\author{
Fima Lifshitz ${ }^{[49]}$, Silvia Diaz-Bensussen, Virginia Martinez-Garza, Felix \\ Abdo-Bassols, and Ernesto Diaz del Castillo \\ Hospital de Pediatria, Centro Medico Nacional, Instituto Mexicano del Seguro Social, Mexico, D.F. Mexico
}

\section{Extract}

The influence of disaccharides on the development of systemic acidosis in premature infants was studied by observing the changes that occurred in the blood after oral administration of carbohydrates. Lactose produced a small rise in levels of reducing sugar in blood, a stepwise increase of lactate concentrations, and a simultaneous drop in blood $\mathrm{pH}$ and $\mathrm{CO}_{2}$ in serum. There were no acid-base alterations, and there was a greater increment in reducing sugars in blood in full-term patients with intrauterine malnutrition (IUM) and in premature infants after month 2 of life.

In premature infants the drop in $\mathrm{pH}$ induced by lactose was significant during the first $15 \mathrm{~min}$ after the oral load and reached the lowest level (mean drop $0.09 \mathrm{pH}$ unit) within 30-45 min with gradual return to the basal point at $120 \mathrm{~min}$. The maximal decrease in bicarbonate concentrations (mean drop $2.63 \mathrm{mEq} /$ liter) occurred at 60-90 min after lactose feeding and was associated with a decrease in chloride concentration in serum (mean drop $7.8 \mathrm{mEq} / \mathrm{liter}$ ) and an increased sodium-tochloride ratio. The increase in levels of lactate in blood did not account for the fall in levels of chloride and could only relate one-ninth of the anion substitution that occurred. In contrast, an equimolar load of mannitol induced none of the above mentioned changes.

Stool composition after lactose loading did not vary in infants given oral loads of carbohydrates. When the maximal functional capacity was exceeded, however, diarrhea was induced, the $\mathrm{pH}$ of the stool dropped to a low of 4.50, and carbohydrates, lactate, and electrolytes were excreted in increased amounts in the feces; simultaneously severe metabolic acidosis ensued. The development of metabolic acidosis after oral loads of lactose was modified neither by neomycin treatment nor by substrate priming. There was an improvement in the response, however, as the infants grew older; those infants who received lactose during day 1 of extrauterine life were the infants who had the most striking decreases in blood $\mathrm{pH}$ values (mean 7.27) and bicarbonate concentrations in serum (mean $17.6 \mathrm{mEq} / \mathrm{liter}$ ).

An oral load of sucrose also produced a small rise in levels of reducing sugars in blood and induced metabolic acidosis, although the response was less intense than that obtained after lactose administration. There was no impairment in monosaccharide metabolism; the absorption of glucose, galactose, and fructose was normal; and the blood $\mathrm{pH}$ values remained stable throughout. All carbohydrates induced lactic acidemia similar to that produced by lactose. 


\section{Speculation}

The observations indicate that disaccharide metabolism in newborn premature infants is impaired. Lactose loads administered orally result in subnormal elevation in reducing sugars in blood and the development of metabolic acidosis. These findings suggest that disaccharidase activity in premature infants is less than that demonstrated by full-term infants and that prematures hydrolyze sugars to a variety of organic acids, lower in the bowel. These, then, are quickly absorbed and produce a prompt metabolic acidosis.

\section{Introduction}

The quantity of disaccharides that can be digested and absorbed by premature infants is limited because of low intestinal disaccharidase activity and reduced total enzyme activity as a function of the small area of intestinal surface $[2,15]$. Disaccharidase deficiencies lead to disaccharide malabsorption with carbohydrate hydrolysis and fermentation occurring mainly by bacterial action. This generates large amounts of organic acids [43] and produces stools with a low $\mathrm{pH}$ and high lactic acid content, as found in newborn infants [40].

Recently, Torres-Pinedo et al. [42] showed that the organic acids generated from carbohydrates in the intestinal lumen play an important role in the disturbances of acid-base equilibrium of infants with diarrhea. These acids are absorbed in part and are neutralized in the gut by secretion of large quantities of cations with loss of bicarbonate, thus increasing the $\mathrm{H}^{+}$ ion concentrations of body fluids. If protons are released by the body, the net effect on acid-base homeostasis will depend on the efficiency of renal acidification and of the body buffering systems [21, 33]. These mechanisms are known to be impaired in premature infants $[17,41]$ and may account for their inability to compensate for the increase in $\mathrm{H}^{+}$ion concentration resulting from disaccharide maldigestion.

This report describes our findings of the influence of disaccharides on the development of systemic acidosis in the premature infant, as reflected by the changes occurring in blood $\mathrm{pH}$ values and levels of $\mathrm{CO}_{2}$ in serum after oral administration of carbohydrates.

\section{Materials and Methods}

One hundred and seventeen healthy premature infants were studied at the Hospital de Pediatria, Centro Medico Nacional, I.M.S.S. The mean birth weight, length, head circumference, and gestational age $\pm 95 \%$ confidence intervals were as follows: $1.57 \pm 0.34 \mathrm{~kg}, 40.9 \pm$ $1.3 \mathrm{~cm}, 28.9 \pm 0.7 \mathrm{~cm}$, and $33.7 \pm 0.9$ weeks, respec- tively. The patients were fed a standard nursery formula after $24 \mathrm{hr}$ of age. The percentage composition of the formula was: lactose, 5.4; protein, 1.2; fat, 2.9; and minerals, 0.3 . The amounts were varied according to the weight of the infants and gradually increased so that by the end of week 1 of life the babies were receiving $150 \mathrm{ml} / \mathrm{kg}$ of body weight in six divided doses. After receiving parental consent, and following a 4-hr fast, each of the patients received an oral load of carbohydrate. Observations were made of subsequent changes in blood $\mathrm{pH}$ values and levels of lactic acid, reducing sugars, $\mathrm{CO}_{2}$, and electrolytes. Lactose, sucrose, glucose, galactose, and fructose [44] were given by stomach tube as a $20 \%$ solution; the dose was 1.75 $\mathrm{g} / \mathrm{kg}$ of body weight, unless otherwise specified. All blood samples were obtained from capillary blood by heel puncture.

In four male premature infants the effect of lactose loading on stool composition was also determined. The feces were collected for a 24-hr basal period before lactose administration, and for a comparable period after the oral load. During each of these consecutive 24-hr intervals the infants were fed the same amount of milk formula. Contamination by the urine was avoided by using a separate collecting system. Each bowel movement was signaled by an electronic device similar to the one described by Kallen and Burg for collection of urine [30], and immediately a weighed aliquot of the stool was placed in a bottle containing $1.0 \mathrm{~N} \mathrm{HCl}$ and $0.04 \% \mathrm{NaFe}$ as preservative for quantification of lactic acid and reducing substances. A second sample was weighed and homogenized, and after centrifugation the supernatant fluid was analyzed for content of sodium, potassium, and chloride. The remainder of each fecal sample was used to determine the wet and dry weight and the $\mathrm{pH}$.

Blood $\mathrm{pH}$ values were determined at the bedside with a glass electrode potentiometer [45], and readings were corrected to $37^{\circ}$. The level of $\mathrm{CO}_{2}$ in serum was determined in a microgasometer [46] as described by 
Natelson [36]. Blood values and levels of lactic acid in feces were measured by the method of Barker and Summerson [3]. Total reducing sugars were determined in blood and gastric content according to the method of Nelson and Somogyi [39]. Reducing substances were analyzed in the gastric and stool contents as described by Folin-Wu [37]. Sodium and potassium levels in serum and in feces were determined with a flame photometer [47], and the chloride level was quantified in an automatic chloridometer [48] by the method of Cotlove et al. [14]. The data were analyzed statistically according to Natrella [38]. The studies were conducted in a $2 \times 2$ factorial design, and a two-variable classification was utilized to perform the analysis of variance of the means [16] unless otherwise specified.

\section{Results}

The responses of 20 premature infants to an oral load of lactose were compared with those of 5 full-term infants with intrauterine malnutrition (IUM), and of 5 control patients (premature infants after month 2 of life) (Fig. 1). Premature infants, less than 3 weeks of age, had a highly significant drop in blood $\mathrm{pH}$ within $15 \mathrm{~min}$ after the disaccharide load. The fall reached a mean maximal value of $0.09 \mathrm{pH}$ unit at 30 and 45 min; a gradual recovery to basal levels occurred by 120 min. In contrast, patients with IUM and control infants had no significant changes in blood $\mathrm{pH}$ values. Simultaneously, in premature infants, a mean drop of $2.63 \mathrm{mEq} /$ liter in the level of $\mathrm{CO}_{2}$ in serum occurred $60 \mathrm{~min}$ after the oral load and remained low thereafter. In infants with IUM a mean drop of $1.75 \mathrm{mEq} /$ liter occurred at $30 \mathrm{~min}$ in the level of $\mathrm{CO}_{2}$ in serum followed by a gradual recovery, and in the control group the serum bicarbonate concentration was not modified from the basal levels by the oral lactose load. In addition to the development of metabolic acidosis, there was a gradual increase in lactate levels in the blood of the premature infants, from a mean basal concentration of 17.08 to $22.20 \mathrm{mg} / 100 \mathrm{ml}$ at $120 \mathrm{~min}$ after the oral load. Patients with IUM did not have a rise in lactate levels (mean of $19.08 \mathrm{mg} / 100 \mathrm{ml}$ ). The control group started with higher basal levels of lactate in blood (mean of $38.16 \mathrm{mg} / 100 \mathrm{ml}$ ) which rapidly decreased at a rate of $0.053 \mathrm{mmole} / \mathrm{liter} / \mathrm{min}$ during the first 30 min after the oral load, remaining stable thereafter. Lactate differences between the three groups of patients were significant and could be accounted for in part by the pattern of physical activity and the response to the gastric intubation before the oral load.

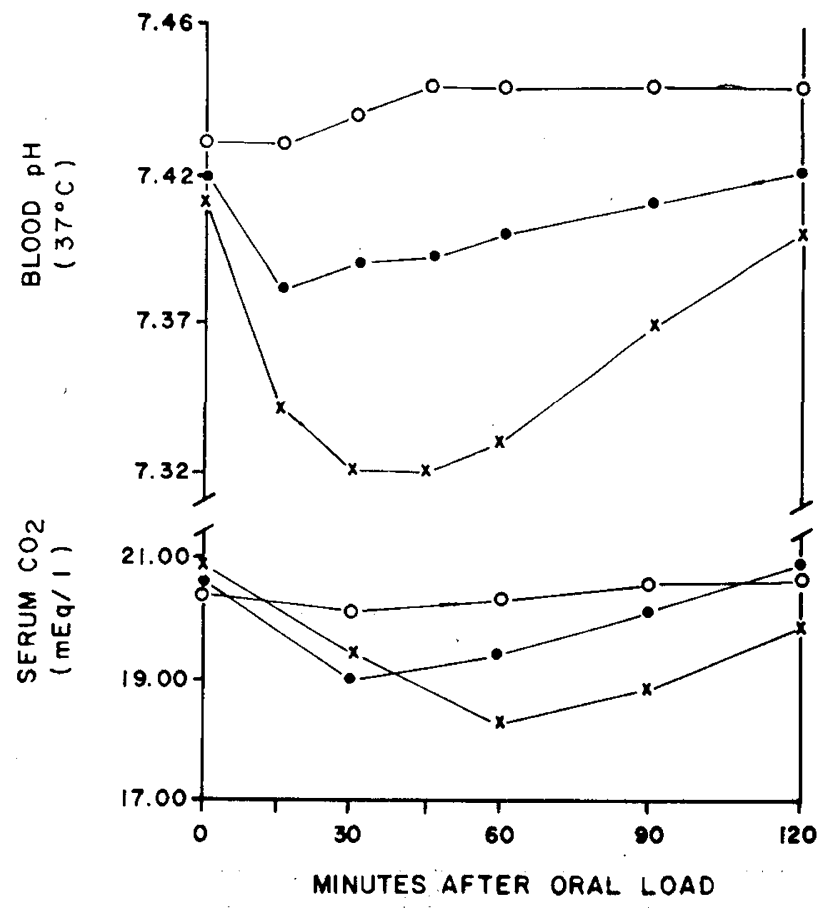

Fig. 1. Changes in blood $\mathrm{pH}$ values and levels of $\mathrm{CO}_{2}$ in serum in response to oral loads of lactose given to infants of varying postconceptual age. Three groups of patients were considered: premature infants, 4-21 days of age $(X)$, with a mean birth weight, length, head circumference, and gestational age as follows: $1.463 \mathrm{~kg}, 40.0 \mathrm{~cm}, 28.0 \mathrm{~cm}$, and 32 weeks, respectively; patients 4-8 days of age with intrauterine malnutrition (•), with a mean birth weight, length, head circumference, and gestational age as follows: $1.733 \mathrm{~kg}, 48.0 \mathrm{~cm}, 33.0 \mathrm{~cm}$, and 39 weeks, respectively; and a control group constituted by premature infants 2-4 months of age $(O)$, with a mean body weight of $4.725 \mathrm{~kg}$ at the time of the study. Differences in the response to the oral load were significant for the premature infants $(P<0.01)$. The least significant difference (LSD) at a $5 \%$ level for blood $\mathrm{pH}$ was 0.07 and for level of $\mathrm{CO}_{2}$ in serum was $1.27 \mathrm{mEq} /$ liter. Data are means. The variance of each mean is shown in Table III. The number of patients studied in each group was 20,5 , and 5 , respectively.

As described by Graven et al. (24), the concentrations of lactate in the blood of infants are directly related to the degree of physical activity, and the levels decrease following rest at a rate of $0.005-0.1 \mathrm{mmole} / \mathrm{liter} / \mathrm{min}$. The stepwise increase in lactate concentrations in blood, however, that occurred in premature infants after the oral load could be related to the lactose administration; this response was similar to the rise observed by others after the infusion of carbohydrate solutions [9, 8, 13, 26]. As expected, the levels of blood reducing sugar (BRS) increased after the oral load of lactose, but the amount, the rate, and the time of maximal elevation over the basal levels differed in the 


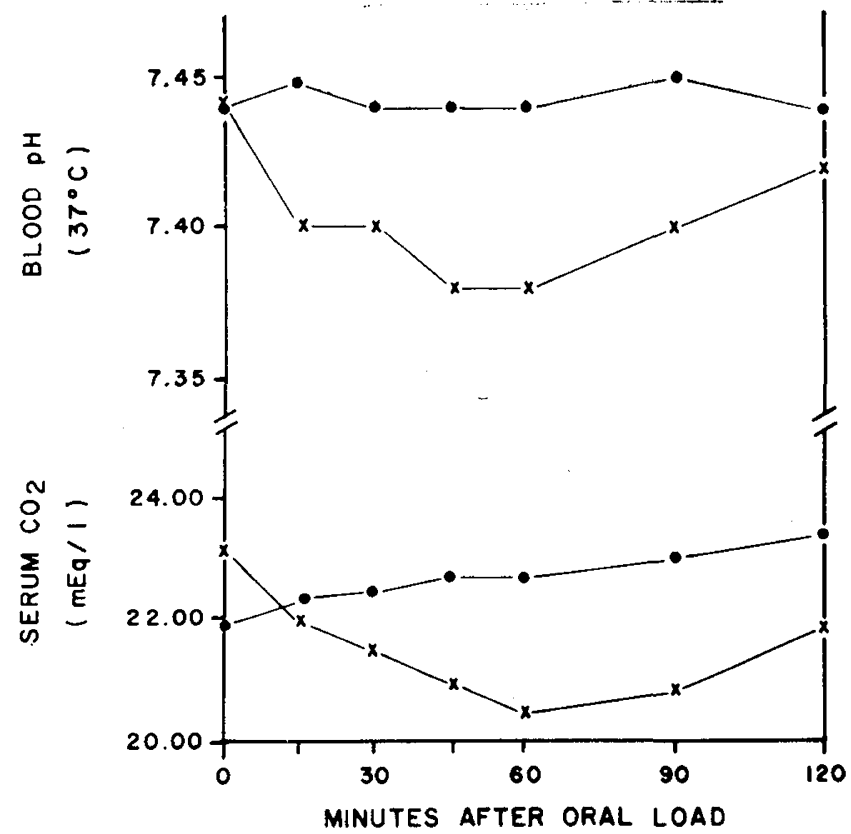

Fig. 2. Comparison of changes in blood $\mathrm{pH}$ values and levels of $\mathrm{CO}_{2}$ in serum of premature infants given oral loads of lactose and mannitol. Five infants were pair-matched for weight $( \pm 50 \mathrm{~g}$ ) and for age ( \pm 1 day). They were studied during the first 3 weeks of life when given lactose orally $(X)$ or when given an equimolar dose of mannitol ( ). After the oral load of lactose blood $\mathrm{pH}$ values fell a mean maximum of 0.06 at 30 and $45 \mathrm{~min}$ and the level of $\mathrm{CO}_{2}$ in serum had a mean maximal drop of 2.52 $\mathrm{mEq} /$ liter at $60 \mathrm{~min}$. In contrast, after the oral load of mannitol no changes were induced. The differences in the response to these oral loads were highly significant $(P<0.001)$. The least significant difference at a $5 \%$ level was 0.04 for blood $\mathrm{pH}$ values and $1.68 \mathrm{mEq} /$ liter for the levels of $\mathrm{CO}_{2}$ in serum. Data are means. The variance of each mean is shown in Table III.

three groups of patients. The premature infants had a diminished absorption of lactose, as reflected by a reduced and delayed elevation in BRS, a phenomenon which has been reported by others [5, 29].

In an attempt to clarify the mechanism producing metabolic acidosis in premature infants by lactose loading by mouth, a study was conducted to evaluate the response to an equimolar load of mannitol (Figs. 2, 3, and 4). The oral load of lactose induced a highly significant drop in blood $\mathrm{pH}$ values and in $\mathrm{CO}_{2}$ levels in serum; in contrast, no changes were produced by mannitol. The bicarbonate loss following lactose was not a $\mathrm{CO}_{2}$-chloride exchange as shown by the simultaneous drop in levels of chloride in serum and rising $\mathrm{Na}: \mathrm{Cl}$ ratios. The decreases of both chloride and bicarbonate levels must be accounted for by the accumulation of other anions, presumably organic acids. Indeed, in addition to the development of meta- bolic acidosis and chloride loss, there was a simultaneous rise in the levels of lactate in blood in all premature infants given lactose, comparable to that seen in children with diarrhea as described by Torres-Pinedo et al. [42]. The amount of lactic acid increase over the basal concentrations $(\Delta)$, however, did not account for the reduction in the levels of chloride in serum, for the maximal lactate value was $0.81 \mathrm{mmole} / \mathrm{liter}$ or only one-ninth of the anion substitution for chloride. Other organic acids with a low $\mathrm{pK}_{a}$ such as those produced in patients with diarrhea due to lack of specific disaccharide-splitting enzymes [43] or after milk administration [42] probably account for the anion substitution; however, they were not measured.

Disaccharide malabsorption might have ultimate

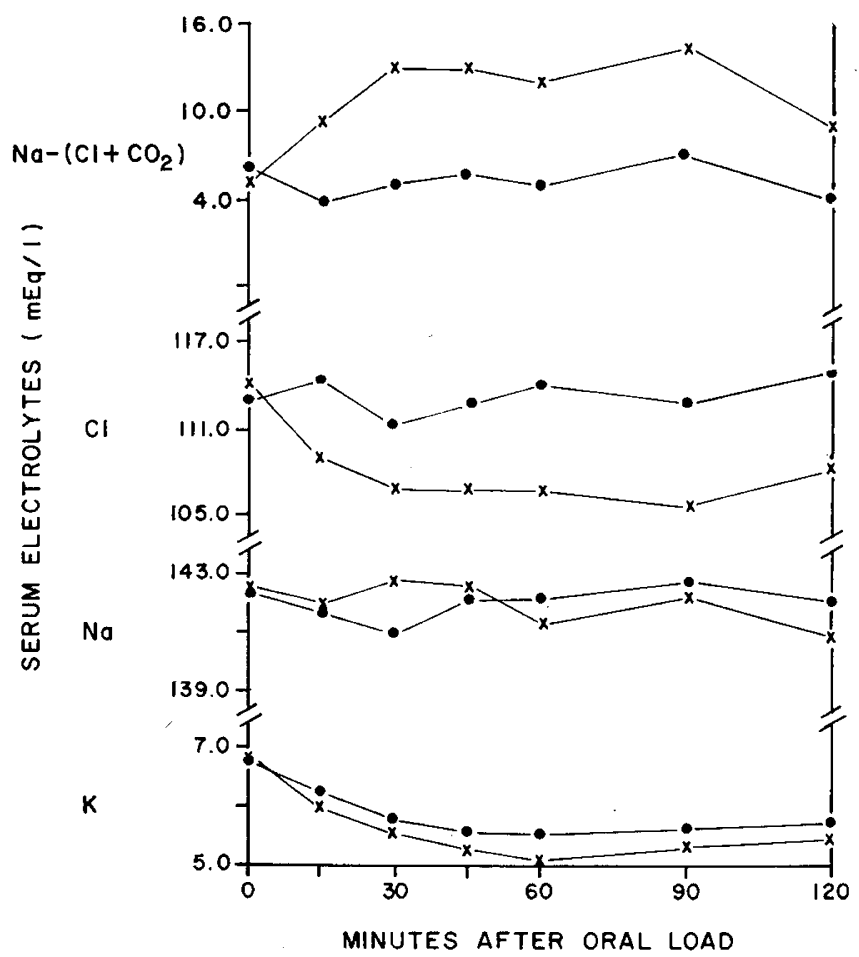

Fig. 3. Changes in electrolytes in serum of premature infants given oral loads of lactose and mannitol. An index of undetermined anions is plotted as the difference between the sodium concentration and the sum of chloride and bicarbonate levels. The differences in the response to these oral loads were highly significant $(P<0.001)$. The least significant difference at a $5 \%$ level was 5.90 for the undetermined anions, and $0.45 \mathrm{mEq} / \mathrm{liter}$ for the chloride levels in serum. Both groups of patients presented a decrease in the potassium concentration in serum after the oral load; however, there were no significant differences among the two groups. This fall was similar to that induced by insulin administration [7]. The data were obtained simultaneously with those depicted in Figures 2 and 4, and the code is the same. The variance of the means is shown in Table III. 
bearing on acid-base balance by altering the final stool composition. None of the patients here described, however, nor those studied by others [5, 29] developed diarrhea after the small oral load of lactose which was sufficient to induce metabolic acidosis. Table I shows data on the stool compositions of two patients ( $I$ and $I I)$ who received this small oral load. There were no fecal changes induced by lactose administration and the 24-hr carbohydrate excretion was below $200 \mathrm{mg} / 24$ $\mathrm{hr}$, a result similar to that found by Ford and Haworth [19]. Since the colon has a large capacity to $a b-$ sorb water and solutes [20], the changes induced by the oral load high in the intestine could have been compensated for by the lower segments, leaving the stool findings unaltered. When the functional capacity of the intestine was tested with the larger dose of lactose $\left(80 \mathrm{~g} / \mathrm{m}^{2}\right.$ of body surface area), which has been used to study infants after recovery from gastroenteritis [12, 34], diarrhea ensued; the $\mathrm{pH}$ of the stools dropped to a low of 4.50; and carbohydrates, lactate, and electrolytes were excreted in increased amounts (Table I). These fecal changes increased progressively to reach a peak and subsequently returned to the initial values, while only $5-10 \%$ of the ingested sugar was recovered as total reducing substances in the stools. Similar findings were reported by Torres-Pinedo et al. [42]. The result of the large lactose load was acidification of body fluids reflected by a marked drop in blood $\mathrm{pH}$ values to a low of $7.224-5 \mathrm{hr}$ after the oral load. In the younger of the two infants tested, metabolic acidosis persisted; and $24 \mathrm{hr}$ after the oral load his blood $\mathrm{pH}$ was only 7.33. The older infant was able to recover to basal levels by the 6th hr.

If proximal intestinal absorption of lactose is partially impaired, the resulting large supply of this carbohydrate to the distal segments of the bowel might cause overproduction of lactic acid and other organic acids as a consequence of fermentation by bacterial action [42, 43]. In order to study the effects of gut sterilization on the development of systemic acidosis induced by lactose, a group of six infants was studied after treatment with neomycin (Fig. 5). These infants also developed metabolic acidosis with elevated levels of lactate in blood. These changes were comparable to those that were induced by oral loading of lactose in previously described groups which had a nonmodified intestinal flora.

Enzyme induction by substrate may in part explain increases in lactase activity and in lactose handling, which occur after birth. A diet containing sucrose has been shown to increase sucrase activity in the intestine

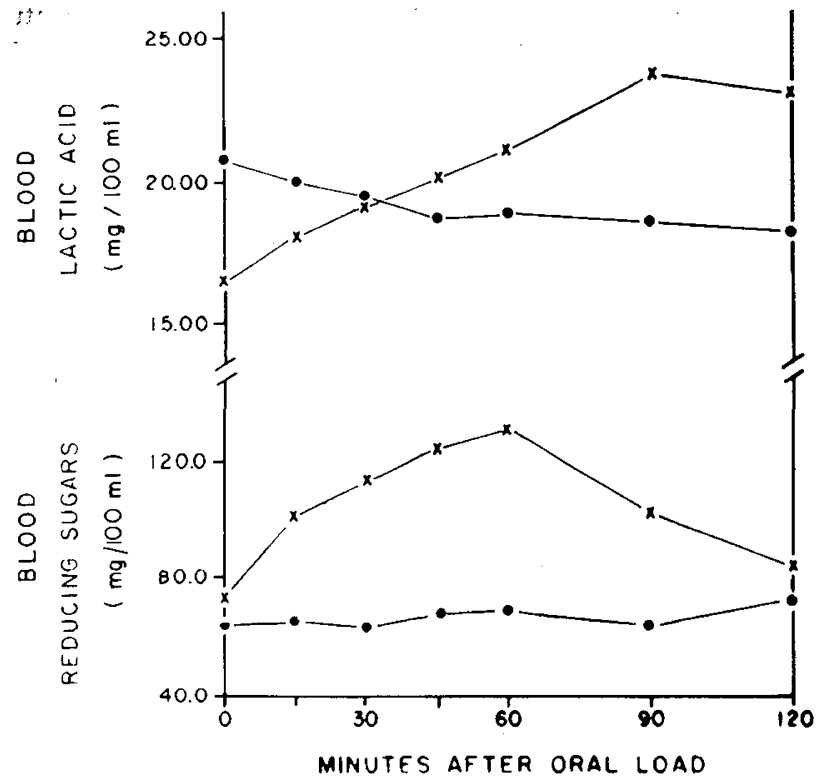

Fig. 4. Changes in lactate and reducing sugar levels in blood of premature infants given oral loads of lactose and mannitol. After the oral load of lactose there was a gradual increase in the lactate levels in blood from a mean basal concentration of $16.52 \mathrm{mg} /$ $100 \mathrm{ml}$ to a maximum of $23.84 \mathrm{mg} / 100 \mathrm{ml}$ at $90 \mathrm{~min}$. In contrast, those given mannitol did not have any rise over the basal levels. The differences in the response to these oral loads were significant $(P<0.001)$. The least significant difference at a $5 \%$ level was $3.22 \mathrm{mg} / 100 \mathrm{ml}$ for the lactic acid, and was $27.88 \mathrm{mg} /$ $100 \mathrm{ml}$ for the reducing sugars. The data were obtained simultaneously with those depicted in the previous two figures, and the code is the same. The variance of the means is shown in Table III.

of rats [4], and lactase activity has been shown to be substrate-induced in microorganisms $[22,23,35]$. If this applies to the human neonate, a diet containing lactose may in part be responsible for stimulating an increase in lactase activity and improvement in lactose tolerance during week 1 of life [5]. Thus, seven 1week-old premature infants were studied after an oral load of lactose that contained the amount of this disaccharide which had been ingested in each formula feeding for the previous 4 days. Again, metabolic acidosis was induced with a high rise in levels of lactate in blood. The results were similar to those depicted in Figure 5. Although these data premit no conclusions as to whether substrate induction occurs in humans, they clearly demonstrate that substrate priming did not prevent the drop in $\mathrm{pH}$ values and the bicarbonate loss after the oral load of lactose with as little as the amount of disaccharide contained in $20-30 \mathrm{ml}$ of milk formula.

A study was designed to determine the influence of 
Table $I$. Fecal findings after lactose oral loads in four premature infants ${ }^{1}$

\begin{tabular}{|c|c|c|c|c|c|c|c|c|}
\hline $\begin{array}{l}\text { Patient } \\
\text { Period }\end{array}$ & A & $I$ & A & B & A & B & A & B \\
\hline $\begin{array}{l}\text { Amount, } \mathrm{g} \\
\% \text { Dry wt }\end{array}$ & \multicolumn{7}{|c|}{$\%$ Dry wt } & 18.4373 \\
\hline Mean & 25.9 & 11.3 & 25.1 & 27.5 & 22.7 & 15.2 & 20.1 & 12.6 \\
\hline Lowest & 18.5 & 8.9 & 16.3 & 23.2 & 19.6 & 4.0 & 17.6 & 3.4 \\
\hline \multicolumn{9}{|l|}{$\mathrm{pH}$} \\
\hline Mean & 6.38 & 6.56 & 6.17 & 6.64 & 5.95 & 5.03 & 5.96 & 5.63 \\
\hline Lowest & 6.15 & 6.52 & 5.97 & 6.62 & 5.81 & 4.54 & 5.80 & 5.01 \\
\hline \multicolumn{9}{|l|}{ Electrolytes, $\mathrm{mEq}$} \\
\hline $\mathrm{Na}$ & 1.24 & 1.48 & 2.56 & 1.99 & 2.56 & 12.83 & 2.83 & 8.49 \\
\hline $\mathrm{K}$ & 5.72 & 7.28 & 16.59 & 15.67 & 8.40 & 40.42 & 17.36 & 28.82 \\
\hline $\mathrm{Cl}$ & 2.11 & 2.42 & 4.42 & 3.87 & 5.51 & 50.12 & 4.47 & 13.70 \\
\hline $\begin{array}{l}\text { Reducing substances, } \\
\text { mg }\end{array}$ & 178.5 & 146.6 & I 42.9 & 97.5 & 71.6 & 698.0 & 123.3 & 490.8 \\
\hline Lactate, mg & 12.93 & 7.39 & 12.83 & 13.81 & 20.50 & 270.49 & 13.10 & 318.52 \\
\hline
\end{tabular}

${ }_{1}$ The changes in the fecal composition of four male patients in response to an oral load of lactose are shown. Period A depicts the basal condition during the $24 \mathrm{hr}$ prior to the tolerance test, and period B shows the values obtained during the same interval following the oral load of lactose. Patients $I$ and $I I$ were given a standard dose of $1.75 \mathrm{~g} / \mathrm{kg}$ of body weight, and patients $I I I$ and $I V$ received a dose of $80 \mathrm{~g} / \mathrm{m}^{2}$. The percentage of dry weight and the $\mathrm{pH}$ of the stools are reported as mean values of all fecal samples of each period; the lowest level found in a single bowel movement is also shown. The total amounts of stool, electrolyte, reducing substance, and lactate excreted in each period are depicted. Some of the clinical findings of patients $I, I I, I I I$, and $I V$, respectively, were as follows: age: $2,10,3$, and 16 days; weight: $1,760,1,900,1,800$, and 1,860 g; birth weight: 1,800, 1,920, 1,740, and 1,760 g; birth length:44.5, $45.0,44.5$, and $44.0 \mathrm{~cm}$; head circumference : $30.0,31.0,30.0$, and $30.5 \mathrm{~cm}$. The gestational age was 35 weeks for all.

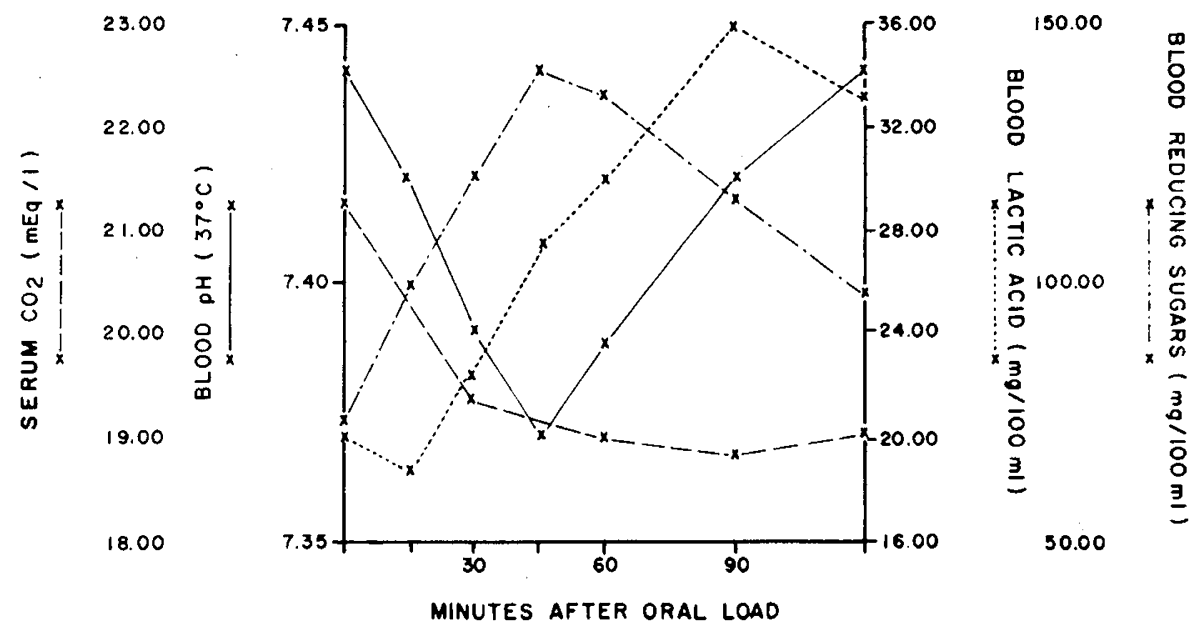

Fig. 5. Changes in blood $\mathrm{pH}$ values and in levels of lactic acid and reducing sugars in blood, and levels of $\mathrm{CO}_{2}$ in serum of six neomycin treated premature infants given lactose orally. The dose of neomycin was $50 \mathrm{mg} / \mathrm{kg} / 24 \mathrm{hr}$, per os from days 3 to 8 of life. The differences from the basal levels were significant for each of the four parameters measured. The analysis of variance of the means was performed by a single variable of classification [38]. The least significant difference at a $5 \%$ level for $\mathrm{pH}$ was 0.04, for $\mathrm{CO}_{2}$ was $1.91 \mathrm{mEq} /$ liter, for lactic acid was $7.60 \mathrm{mg} / 100 \mathrm{ml}$, and for reducing sugars was $15.87 \mathrm{mg} / 100 \mathrm{ml}$. Data are means. The variance of the means is shown in Table III.

age on the response to oral loads of lactose, and to evaluate the changes induced by another disaccharide, namely sucrose, and a monosaccharide, glucose. The changes in blood $\mathrm{pH}$ values induced by these sugars are shown in Figure 6. There was a difference in the response of premature infants to each of these loads: those receiving lactose presented a highly significant drop in blood $\mathrm{pH}$ values within $15 \mathrm{~min}$ after the oral load, whereas those given glucose manifested no changes. The infants given sucrose showed a significant fall in $\mathrm{pH}$, but it was less intense than that obtained after lactose administration. Age did not mod- 

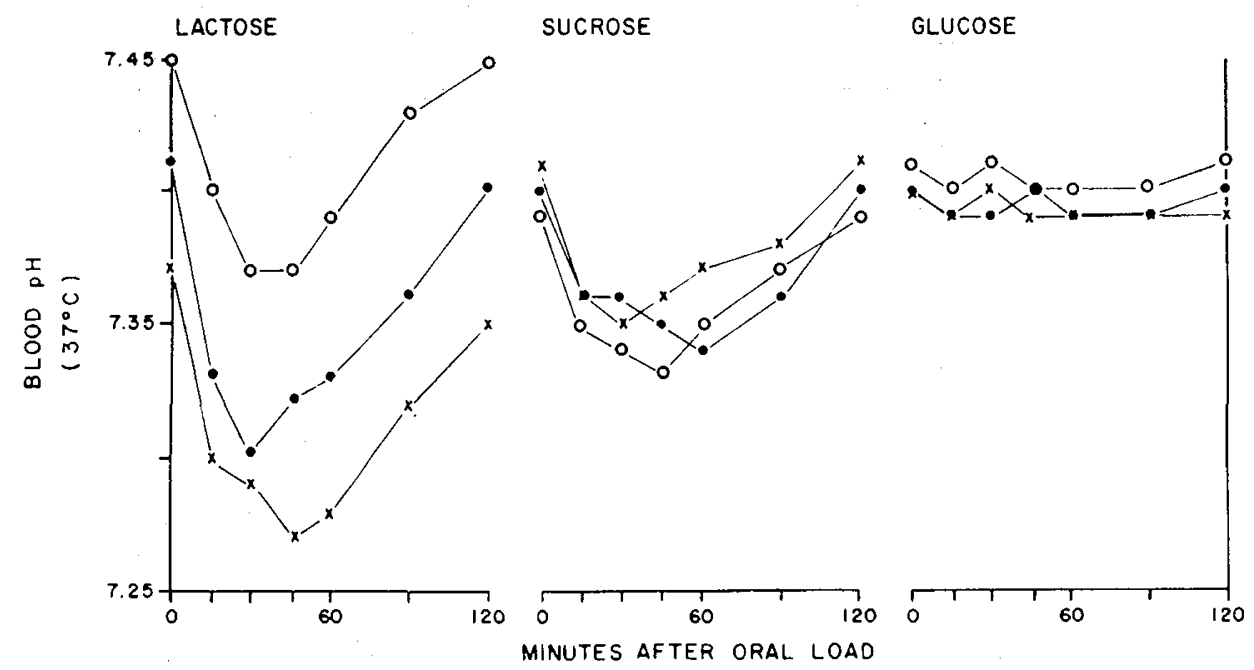

Fig. 6. The variation as a function of age in the response of blood $\mathrm{pH}$ values of premature infants to oral loads of three different carbohydrates. Lactose, sucrose, and glucose were given to three groups of infants: those less than $24 \mathrm{hr}$ of age, prior to the first feeding $(X)$; those 3-5 days of age $(\bullet)$; and those 20-21 days of age (O). The carbohydrate administered was randomly selected. The differences in the response to each of these oral loads were highly significant $(P<0.001)$ for the three age groups. The least significant difference (LSD) at a $5 \%$ level for groups I and II was 0.06 and for group III was 0.05 . The influence of age was significant for the lactose groups $(P<$ $0.001)$. The LSD was 0.06 . Data are means. The $95 \%$ confidence interval for these means ranged from 0.019 to 0.042 at any of the times depicted. The number of patients studied in each group varied from five to seven.

ify the response of blood $\mathrm{pH}$ values after glucose or sucrose administration. As the infants grew older, however, the fall in blood $\mathrm{pH}$ values in response to lactose was diminished. The patients tested with lactose prior to the first feeding were the ones with the most striking fall in blood $\mathrm{pH}$; subsequently, with advancing age, this drop was less marked. The improvement presumably reflected maturation more than enzyme induction by substrate. No attempts were made to clarify the response to repeated lactose loadings in the same infant.

The differences according to age in the response of the premature infants to oral loads of carbohydrate as reflected by changes in bicarbonate in serum and levels of lactic acid and reducing sugars in blood are shown in Table II. The $\mathrm{CO}_{2}$ concentration dropped after the oral load of each of the three carbohydrates; however, the basal level, the intensity of the fall, and the rate of recovery were influenced by the age of the infants and by the type of sugar administered. Higher basal levels were attained as the infants grew older in the three groups studied. The lowering of $\mathrm{CO}_{2}$ levels in the premature infants produced by lactose during day 1 of life was the most marked and persisted throughout the $120 \mathrm{~min}$; the mean maximal drop in bicarbonate concentrations in serum was $3.2 \mathrm{mEq} /$ liter at $60 \mathrm{~min}$ after the oral load. In contrast, when lactose was administered to infants who were 3-5 days of age, mean bicar- bonate fall was $2.3 \mathrm{mEq} /$ liter, and in the 3-week-old infants it was only $1.5 \mathrm{mEq} /$ liter. After the oral load of sucrose bicarbonate concentrations in serum fell a mean maximum of $2.5,1.9$, and $1.9 \mathrm{mEq} /$ liter in the three groups, respectively; and after the glucose load the drop was never more than $1.3 \mathrm{mEq} /$ liter in any of the groups tested.

The lactate concentrations in blood were similarly increased by the oral load of the three carbohydrates, and the differences in the $\Delta$ lactate levels induced by lactose, sucrose, and glucose were not significant. The basal levels and the amount of increase, however, were influenced by the age of the patient: lower basal levels and smaller rises in levels of lactate in blood were observed as the infants grew older. As mentioned before, the effect of various carbohydrates in producing lacticacidemia has previously been shown in human subjects $[9,8,13,26]$. It appears that lactate accumulation is the result rather than the cause of the development of metabolic acidosis in the premature infant, since blood $\mathrm{pH}$ changes quickly bring about lactate increments [27, 28].

As shown by the lowermost rows of Table II, the elevation of concentrations of BRS was influenced by the type of carbohydrate given and by the age of the patient. After the oral load of either of the disaccharides there was a diminished rise in levels of BRS compared with the one induced by glucose. The differ- 
Table II. Bicarbonate concentrations in serum and lactic acid and reducing sugar levels in blood of premature infants given carbohydrate challenges ${ }^{1}$

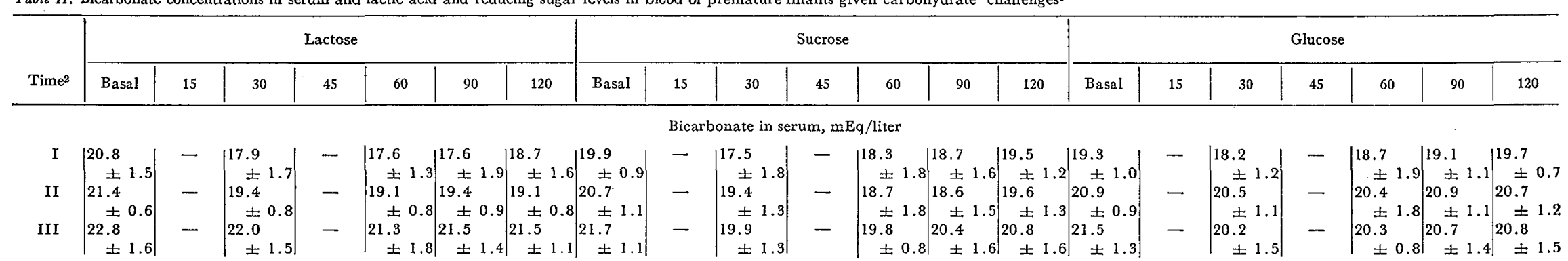

Lactic acid in blood, $\mathrm{mg} / 100 \mathrm{ml}$

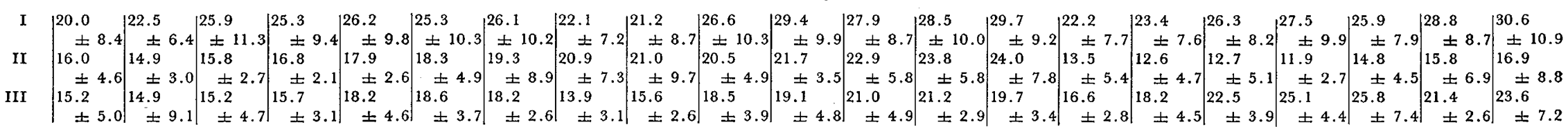
$| \pm 5.0| \pm 9.1| \pm 4.7| \pm 3.1| \pm 4.6| \pm 3.7| \pm 2.6| \pm 3.1| \pm 2.6| \pm 3.9| \pm 4.8| \pm 4.9 \mid$
Reducing sugars in blood, $\Delta \mathrm{mg} / 100 \mathrm{ml}$

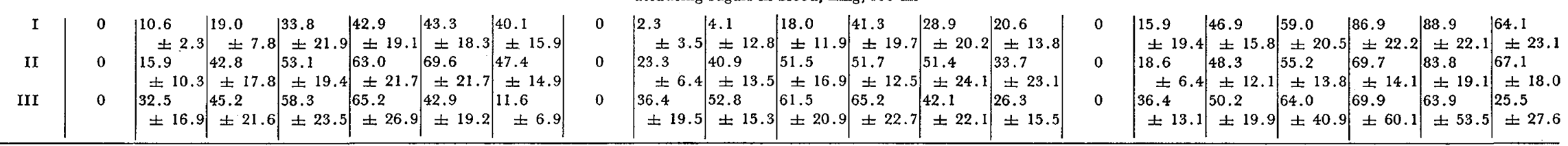

${ }^{1}$ The variation in the response of premature infants to different oral loads of carbohydrates is shown. The concentrations of $\mathrm{CO}_{2}$ in serum, lactic acid in blood, and $\Delta$ reducing sugars are recorded.The least significant dif-

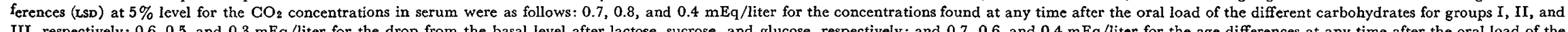
III, respectively; $0.6,0.5$, and $0.3 \mathrm{mEq} /$ liter for the drop from the basal level after lactose, sucrose, and glucose, respectively; and $0.7,0.6$, and $0.4 \mathrm{mEq} / \mathrm{iter}$ for the age differences at any time after the oral load of the three carbohydrates, respectively. The lactate rise was similar in all age groups tested, and the differences were not significant; the IsD at $5 \%$ level for the blood lactic acid concentrations were $4.0,1.5$, and $1.9 \mathrm{mg} / 100 \mathrm{ml}$ for the rise over the basal level after lactose, sucrose, and glucose, respectively; and 6.2,2.2, and 2.9 for the age differences at any time after the oral load of the three carbohydrates, respectively. The $2.5 \mathrm{D}$ at $5 \%$ level for the $\Delta$ blood reducing sugars were as follows: $14.6,11.4$, and $7.3 \mathrm{mg} / 100 \mathrm{ml}$ for the concentrations found at any time after the oral load of the different carbohydrates for groups I, II, and III, respectively; $10.8,9.7$, and
11.6 for the rise over the basal level after lactose, sucrose, and glucose, respectively; and 21.3, 14.8 , and 19.3 for the age differences in blood reducing sugar levels at any time after the oral load of the three carbohydrates, respectively. Data are means $\pm 95 \%$ confidence intervals. The number of patients studied in each group varied from five to seven.

2 Minutes after load. 
Table III. Variance of means ${ }^{1}$

\begin{tabular}{|c|c|c|c|c|c|c|c|}
\hline $\operatorname{Time}^{2}$ & 0 & 15 & 30 & 45 & 60 & 90 & 120 \\
\hline \multicolumn{8}{|c|}{ Fig. 1} \\
\hline Controls & 0.028 & 0.018 & 0.018 & 0.039 & 0.028 & 0.016 & 0.029 \\
\hline IUM & 0.030 & 0.040 & 0.032 & 0.029 & 0.028 & 0.018 & 0.038 \\
\hline Prematures & 0.018 & 0.030 & 0.025 & 0.016 & 0.019 & 0.023 & 0.028 \\
\hline \multicolumn{8}{|c|}{$\mathrm{CO}_{2}$ in serum } \\
\hline Controls & 0.95 & - & 0.75 & 一 & 0.78 & 0.83 & 0.68 \\
\hline IUM & 0.88 & - & 1.48 & - & 1.02 & 0.76 & 1.82 \\
\hline Prematures & 1.32 & - & 1.16 & - & 0.63 & 1.02 & 0.96 \\
\hline \multicolumn{8}{|c|}{ Fig. 2} \\
\hline \multicolumn{8}{|c|}{ Blood $\mathrm{pH}$} \\
\hline Lactose & 0.018 & 0.025 & 0.034 & 0.019 & 0.021 & 0.059 & 0.064 \\
\hline Mannitol & 0.034 & 0.035 & 0.025 & 0.015 & 0.018 & 0.023 & 0.020 \\
\hline \multicolumn{8}{|c|}{$\mathrm{CO}_{2}$ in seruim } \\
\hline Lactose & 1.38 & 1.03 & 1.48 & 1.97 & 1.87 & 1.57 & 1.41 \\
\hline Mannitol & 1.70 & 0.98 & 0.75 & 0.60 & 0.78 & 1.28 & 1.88 \\
\hline \multicolumn{8}{|c|}{$\begin{array}{c}\text { Fig. } 3 \\
\mathrm{~K} \text { in serum }\end{array}$} \\
\hline Lactose & 0.63 & 0.55 & 0.49 & 0.45 & 0.44 & 0.88 & 0.56 \\
\hline Mannitol & 1.22 & 1.43 & 0.67 & 0.26 & 0.62 & 0.52 & 0.64 \\
\hline \multicolumn{8}{|c|}{$\mathrm{Na}$ in serum } \\
\hline Lactose & 7.05 & 6.54 & 3.88 & 6.80 & 6.72 & 4.24 & 6.97 \\
\hline Mannitol & 8.99 & 4.03 & 7.22 & 5.59 & 4.10 & 7.88 & 4.71 \\
\hline \multicolumn{8}{|c|}{$\mathrm{Cl}$ in serum } \\
\hline Lactose & 7.14 & 5.20 & 3.02 & 4.25 & 4.42 & 5.05 & 6.09 \\
\hline Mannitol & 12.85 & 3.76 & 6.06 & 4.13 & 6.79 & 5.98 & 5.75 \\
\hline \multicolumn{8}{|c|}{ Fig. 4} \\
\hline \multicolumn{8}{|c|}{ Lactic acid in blood } \\
\hline Lactose & 3.82 & 4.61 & 3.56 & 4.93 & 2.01 & 5.75 & 2.33 \\
\hline Mannitol & 4.99 & 7.32 & 2.66 & 5.78 & 3.22 & 2.86 & 2.05 \\
\hline \multicolumn{8}{|c|}{ Reducing sugars in blood } \\
\hline Lactose & 16.0 & - & 26.7 & - & 23.5 & 17.4 & 15.8 \\
\hline Mannitol & 10.2 & - & 15.3 & - & 18.0 & 16.7 & 12.3 \\
\hline \multicolumn{8}{|c|}{ Fig. 5} \\
\hline Blood pH & 0.015 & 0.035 & 0.038 & 0.051 & 0.024 & 0.026 & 0.007 \\
\hline $\mathrm{CO}_{2}$ & 1.15 & - & 1.72 & - & 1.76 & 1.54 & 1.03 \\
\hline Lactic acid & 9.57 & 4.16 & 6.34 & 5.39 & 6.86 & 9.45 & 6.90 \\
\hline Reducing sugars & 14.0 & 12.3 & 8.2 & 17.5 & 15.8 & 14.0 & 11.9 \\
\hline
\end{tabular}

${ }^{1}$ Data are $95 \%$ confidence intervals for each of the means dépicted in Figures 1 to 5.

${ }^{2}$ Minutes after load.

ences were significant in the case of the two groups of younger infants but were not significant for the older infants. These data indicate an impairment in lactose and sucrose metabolism but not in glucose absorption during the first few days of life of premature infants and are similar to those reported by others [5, 29]. Also, there was a delayed return of blood reducing sugar to fasting levels during all carbohydrate tolerance tests. This slow disappearance of exogenous glucose from the blood has been reported by others [5, 13], as has the accelerated removal after the first few days of life [6].

Since both disaccharides tested produced a drop in blood $\mathrm{pH}$ values and $\mathrm{CO}_{2}$ levels, the possibility existed that this was the result of hydrolysis to the constituent monosaccharides other than glucose. Thus, three infants were given galactose and three others received oral loads of fructose. The results obtained were similar to those depicted previously for glucose. There were no significant blood changes induced; the bicarbonate concentrations in serum fell a mean maximum of $1.6 \mathrm{mEq} /$ liter and there was an increase in concentrations of lactate in blood that reached a mean maximal increment of 1.4 mmoles/liter at $90 \mathrm{~min}$ after oral loads of both monosaccharides. This rise in the level of lactate was the highest attained after any of the carbo- 


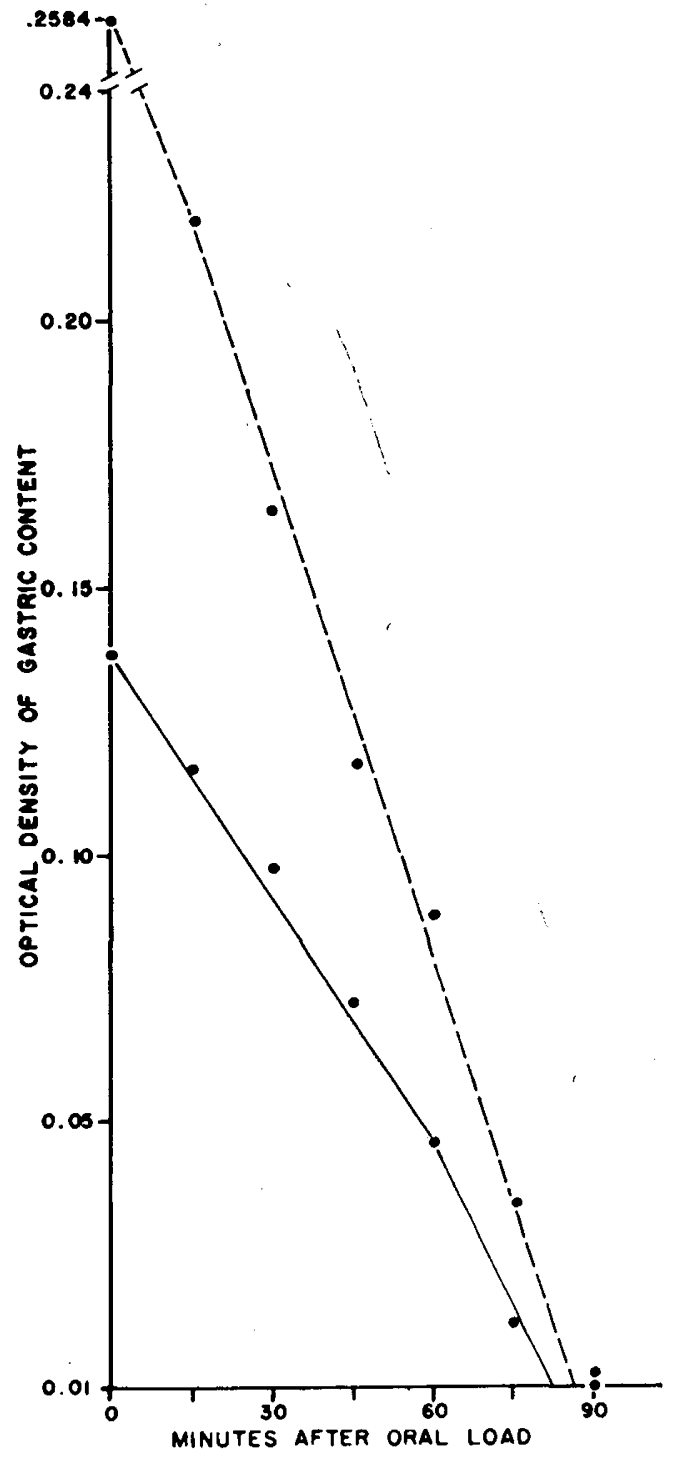

Fig. 7. The gastric emptying time after oral loads of lactose, mannitol, and glucose. Optical density was determined after the gastric content was analyzed by the method of Nelson-Somogyi [39] (-૯) and by the method of Wu [37] (-- $\bullet$ ). The reducing power was corrected for each carbohydrate given, the depicted basal levels being the ones attained immediately after the administration of the sugar minus the ones present before it. There were no differences in the rate of disappearance of the three different oral loads; thus, the results were grouped together. Data are means. Three patients were given lactose, two were given glucose, and three were given mannitol.

hydrate loads and correlated with a greater rise in BRS.

Some of the differences in response to the oral carbohydrate loads as well as the rapidity of the changes induced by disaccharides could be explained by varia- tions in the velocity of gastric emptying time. A rough estimate of this rate was made by serial determinations of the gastric sugar content after lactose, glucose, and mannitol, as shown in Figure 7. Each of these hypertonic solutions rapidly disappeared from the gastric content; thus, the site of production of the metabolic changes that lead to the development of metabolic acidosis within minutes after an oral load of lactose did not seem to be the stomach. However, no attempt was made to elucidate further the exact portion of the small intestine where the changes might be occurring.

\section{Discussion}

The foregoing results indicate that disaccharide metabolism in normal premature infants is impaired. Oral loads of carbohydrates produced a lesser elevation of BRS than in mature infants and induced the development of metabolic acidosis. A gradual improvement in lactose tolerance occurred as the infants grew older, greater increments in BRS were observed, and after month 2 of extrauterine life or after week 38 of gestational age no $\mathrm{pH}$ or bicarbonate changes were detectable in either premature infants or full-term patients with IUM. There was no impairment in monosaccharide metabolism, absorption of glucose, galactose, and fructose being normal and blood values remaining stable from day 1 of life onwards.

The human fetus has disaccharidase activity after month 3 of intrauterine life [2] consisting only of $\alpha$-glucosidase activity, namely maltase and sucrase. This reaches a maximum during months $6-7$ of gestation and remains high thereafter. The $\beta$-glucosidase activity, namely lactase, develops less rapidly during antenatal existence and peaks at the end of normal gestation $[2,15]$. Premature infants thus have a low level of lactase activity that rises rapidly during the early period of extrauterine life. This enzyme insufficiency could be responsible in part for the impairment of lactose hydrolysis and the development of metabolic acidosis; the maturation of the enzyme system brings about an improvement in disaccharide absorption and blood $\mathrm{pH}$ values and bicarbonate concentrations in serum remain stable after oral ingestion of the sugar. Since final digestive process of lactose takes place in the small intestine [25], factors other than a primary enzyme deficiency may be responsible for the impairment in lactose absorption during the neonatal period. Indeed, full-term infants also have impaired lactose metabolism during the first $11 \mathrm{hr}$ of life [1]. The possibility of poor mucosal contact with the disaccharide 
molecule, thus preventing hydrolysis, requires consideration.

Whatever the mechanism producing impaired absorption of lactose in premature infants, its metabolism is accompanied by an alteration in the $\mathrm{H}^{+}$ion concentrations of body fluids. Whether these changes emerge directly from the hydrolysis of disaccharide in the intestinal lumen or within the mucosal cells, or indirectly as a consequence of the disturbance produced in intestinal function by the unabsorbed carbohydrate remains moot. The decrease of both chloride and bicarbonate levels accompanying the changes in the $\mathrm{H}^{+}$composition must be accounted for by the accumulation of other anions such as those produced in patients with diarrhea $[42,43]$ in addition to lactic acid. The increased concentration of lactate was not sufficient to account for the increase in anions other than chloride and bicarbonate. It is probable that the unabsorbed disaccharides are somehow rapidly degradated, at least in part, to organic acids despite the apparent deficiency of mucosal disaccharidases. Most of these organic anions are quickly absorbed and produce a prompt metabolic acidosis. The remaining part is lost in the intestinal fluid and is neutralized by the gut with secretion of large quantities of cations and a loss of bicarbonate [42].

The clinical symptoms of disaccharide malabsorption result from an inbalance between the intestinal disaccharidase activity and the disaccharide load. The standard loads employed in these and other studies [5, 29] produced no stool changes, possibly because the lower segments of the bowel compensated by complete reabsorption of the increased amounts of water and solutes delivered from above [20]. Double lumen intubation studies of different segments of the intestine might yield information to clarify these points. When the functional capacity was exceeded with a larger amount of lactose, however, the patients developed severe metabolic acidosis and, in addition, diarrhea, evidence of carbohydrate malabsorption, and alterations in the final stool composition with increased excretion of electrolytes and lactic acid. This larger dose is well tolerated by infants following recovery from severe gastroenteritis [12, 34]. Although for practical purposes the effect of diarrhea on acid-base balance can be ascertained from sodium, potassium, and chloride measurements of stool, a more refined analysis with consideration of all anions and cations excreted in the feces after oral disaccharide loads may further elucidate the organic anion content of feces.
The production of organic acids by intestinal bacteria has been shown to play a role in the development of acidosis in infants with diarrhea [42] and in sheep $[10,11]$. In the premature infant, however, it may be that anions are largely generated within the body rather than by bacterial fermentation, since in the present experiments neomycin treatment did not influence the development of metabolic acidosis after lactose administration. It should be kept in mind, however, that this antibiotic will lower the bacterial content of the bowel but not sterilize it. The type, the specific quantities, and the exact portion of the bowel where the anions are generated after oral loads of lactose remain to be determined.

Although there were no alterations in blood $\mathrm{pH}$ values detected in mature infants after lactose administration, the possibility that they also accumulated anions cannot be excluded, since increased buffer capacity may have obscured this effect. Nevertheless, the present observations do not eliminate the possibility that unhydrolyzed disaccharides, through their action on stool volume, exert a sweeping effect on water, cations, and anions secreted and reabsorbed at different segments of the bowel [31, 32], and the resultant change in blood acid-base equilibrium of premature infants reflects only the efficiency of their compensatory mechanisms [21, 41].

Of interest are the rapid onset of the lowering of blood $\mathrm{pH}$ values and levels of bicarbonate concentration in serum and the remarkably rapid correction of the acidosis with values returning to base line within 2 $\mathrm{hr}$. The recovery of these variables to basal levels suggests that the organic acids are quickly metabolized to $\mathrm{CO}_{2}$ and $\mathrm{H}_{2} \mathrm{O}$ since correction by the kidney would be expected to take considerably longer [18]. The exact role of this organ will have to be studied to determine the pattern of change in renal acid excretion after disaccharide ingestion.

\section{Summary}

Oral loads of lactose induced metabolic acidosis in premature infants which was accompanied by an anion substitution for chloride. Lactate accounted for one-ninth of this substitution. No changes in stool composition were observed as long as maximal functional capacity was not exceeded. Neither neomycin treatment nor substrate priming modified these responses; however, advanced age produced a diminished response. Sucrose caused a similar effect while monosaccharides or other osmotic loads, e.g., mannitol, 
caused no such alterations. These observations indicate that disaccharide metabolism in newborn premature infants is impaired.

\section{References and Notes}

1. Anyon, G. P., and Clarkson, K. G.: Lactose metabolism in the newborn. Gastroenterology, 51: 120 (1966).

2. Auricchio, S., Rubino, A., AND MURSET, E.: Intestinal glycosidase activities in the human embryo, fetus and newborn. Pediatrics, 35: 944 (1965).

3. Barker, S. B., ANd Summerson, W. H.: The colorimetric determination of lactic acid in biological material. J. Biol. Chem., 138: 535 (1941).

4. Blair, D. G. R., Yakimets, W., and Tuba, J.: Rat intestinal sucrase. II. The effects of rat age and sex and of diet on sucrase activity. Can. J. Biochem., 41: 917 (1963).

5. Botllner, S. W., Beard, T. G., Panos, T. C., and Ross, A.: Impairment of lactose hydrolysis in newborn infants. Pediatrics, 36: 542 (1965).

6. Bowie, M. D., Mullican, P. B., ANd Schwartz, R.: Intravenous glucose tolerance in the normal newborn infant: The effects of a double dose of glucose and insulin. Pediatrics, 31 : 590 (1963).

7. Briggs, A. P., AND Koechig, I.: Some changes in composition of blood due to the injection of insulin. J. Biol. Chem., 58: 721 (1923).

8. BUEDING, E., ANd Goldfarb, W. J.: Blood changes following glucose, lactate and pyruvate injections in man. J. Biol. Chem., 147: 33 (1943).

9. Bueding, E., Stein, M. H., ANd Wortis, H.: Blood pyruvate curves following glucose ingestion in normal and thiaminedeficient subjects. J. Biol. Chem., 140: 697 (1941).

10. BulleN, J. J., AND BATTY, I.: Experimental enterotoxaemia of sheep: The effect of the permeability of the intestine and the stimulation of antitoxin production in immune animals. $\mathrm{J}$. Pathol. Bacteriol., 73: 511 (1957).

11. Bullen, J. J., AND SCARIsbrick, R.: Enterotoxaemia of sheep: Experimental reproduction of the disease. J. Pathol. Bacteriol., 73: 495 (1957).

12. Coello-Ramirez, P., Gutierrez-Topete, G., and Lifshitz, F.: Pneumatosis intestinalis. Amer. J. Dis. Child., 120: 3 (1970).

13. Cornblath, M., Wybregt, S. H., and BaENS, G. S.: Studies of carbohydrate metabolism in the newborn infant. VII. Tests of carbohydrate tolerance in premature infants. Pediatrics, 32: 1007 (1963).

14. Cotlove, E., Tratham, H. V., and Bowma, R. L.: Instrument and method for automatic, rapid, accurate and sensitive titration of chloride in biological samples. J. Lab. Clin. Med., 50: 358 (1958).

15. DAhlQvist, A., AND Linberg, T.: Development of intestinal disaccharidases and alkaline phosphatase activities in human foetus. Clin. Sci., 30:527 (1966).

16. Dixon, W. J., AND Massey, F. J.: In: Introduction to Statistical Analysis, p. 155 (McGraw-Hill, New York, 1957).

17. Dreschner, A. N., Barnett, H. L., ANd Troupkou, V.: Water balance in infants during water deprivation. Amer. J. Dis. Child., 104: 366 (1962).

18. Foman, S. J., Harris, D. M., and Jensen, R.: Acidification of the urine of infants fed human milk and whole cow's milk. Pediatrics, 23: 113 (1959).

19. Ford, J. D., AND HaWorTh, J. L.: The fecal excretion of sugars in children. J. Pediat., 63: 988 (1963).

20. Fordtran, J. S.: Speculations on the pathogenesis of diarrhea. Fed Proc., 26: 1405 (1967).

21. Goodman, A. D., Lemann, J., JR., Lennon, E. J., and Reiman, A. S.: Production, excretion and net balance of fixed acid in patients with renal acidosis. J. Clin. Invest., 44: 495 (1965).

22. Grand, D. J. W., AND Hinshelwood, C.: Studies on the enzyme activity of Bact. Lactis Aerogenes (Aereobacter aerogenes). I. The effects of cellular disruption on the activities of some typical enzymes. Proc. Roy. Soc. Ser. B. Biol. Sci., 160: 25 (1964).

23. Grand, D. J. W., and Hinshelwood, C.: Studies of the enzyme activity of Bact. Lactis Aerogenes (Aerobacter aerogenes). II. The effects of various adaptions on the enzyme balance. Proc. Roy. Soc. Ser. B. Biol. Sci., 160: 42 (1964).

24. Graven, S. N., Criscuolo, D., And Holcomb, T. M.: The effect of activity on the concentrations of blood lactate in newborn infants. Pediatrics, 37: 278 (1966).

25. Gray, G. M.: Malabsorption of carbohydrate. Fed. Proc., 26: 1415 (1967).

26. Нгмшісн, H. E.: The role of lactic acid in the living organism. Yale J. Biol. Med., 4: 259 (1931-1932).

27. Huckabee, W. E.: Relationships of pyruvate and lactate during anaerobic metabolism. I. Effects of infusion of pyruvate or glucose and of hyperventilation. J. Clin. Invest., 37: 244 (1958).

28. HuCKABEE, W. E.: Relationships of pyruvate and lactate during anaerobic metabolism. II. Exercise and formation of $\mathrm{O}_{2}$-debt. J. Clin. Invest., 37: 255 (1958).

29. Jarret, E. C., and Holman, G. H.: Lactose absorption in the premature infant. Arch. Dis. Child., 41: 525 (1966).

30. Kallen, R. J., and Burg, F.: An electronic aid for timing urine collection periods in non-catheterized infants. Pediatrics, 30: 703 (1964).

31. Launiala, K.: The mechanism of diarrhoea in congenital disaccharide malabsorption. Acta Paediat. Scand., 57: 425 (1968).

32. Launiala, K.: The effect of unabsorbed sucrose and mannitol on the small intestine flow rate and mean transit time. Scand. J. Gastroenterol., 39: 665 (1968).

33. Lemann, J., JR., Lennon, E. J., Goodman, A. D., Litzow, J. R., and ReLman, A. S.: The net balance of fixed acid in subjects given large loads of acid or alkali. J. Clin. Invest., 44: 507 (1965).

34. Lifshitz, F., Coello-Ramirez, P., and Gutierrez-Topete, G.: Monosaccharide intolerance and hypoglycemia in infants with diarrhea. I. Clinical evolution of 23 cases. J. Pediat., 77: 595 (1970).

35. Monod, J., Cohenobazire, G., And Cohn, M.: Sur la biosynthese de la B-galactosidase (lactase) chez Escherichia coli. La specificite de l'induction. Biochim. Biophys. Acta., 7: 585 (1951).

36. NAtelson, S.: In: Microtechniques of Clinical Chemistry, p. 162 (Thomas, Springfield, I1l., 1961).

37. Natelson, S.: In: Microtechniques of Clinical Chemistry, p. 215 (Thomas, Springfield, Ill., 1961).

38. Natrella, M. G.: Experimental Statistics (National Bureau of Standards Handbook 91, Washington, D. C., 1963). 
39. Nelson, N.: A photometric adaptation of the Somogyi method for the determination of glucose. J. Biol. Chem., 153: 375 (1944).

40. Prader, A., and Auricchio, S.: Defects of intestinal disaccharide absorption. Annu. Rev. Med., 16: 343 (1965).

41. Rubin, M. L., Calcagno, P. L., and Reuben, B. L.: Renal excretion of hydrogen ions: A defense against acidosis in premature infants. J. Pediat., 59: 848 (1961).

42. Torres-Pinedo, R., Lavastida, M., Rivera, C. L., Rodriguez, H., AND ORTIZ, A.: Studies on infant diarrhea. I. A comparison of the effects of milk feeding and intravenous therapy upon the composition and volume of the stool and urine. $J$. Clin. Invest., 45: 469 (1966).
43. WejJers, H. A., Van de Kamer, J. H., Dicke, W. E., AND IJSSELING, J.: Diarrhoea caused by deficiency of sugar-splitting enzymes. I. Acta Paediat., 50: 55 (196I).

44. Mallinkrodt and Pfanstiehl Laboratories, St. Louis, Mo.

45. Model $\mathrm{G}$ pH meter, Beckman Instruments, Inc., Fullerton, Calif.

46. Model 600, Scientific Industries, Inc., Springfield, Mass.

47. Model 21, Coleman Instruments Company, Maywood, Ill.

48. Buchler-Cotlove, Buchler Instruments, Inc., Fort Lee, N. J.

49. Requests for reprints should be addressed to: Fima Lifshitz, M.D., University of Maryland Hospital, Redwood and Green Streets, Baltimore, Maryland 21201 (USA).

50. Accepted for publication May 21, 1970. 